\title{
Is the information about dengue available on Brazilian websites of quality and reliable?
}

\author{
As informações sobre dengue disponíveis em \\ websites brasileiros são de qualidade e confiáveis?
}

Thiago Henrique de Lima1', Ivandilson Pessoa Pinto de Menezes², Guilherme Malafaia²

'Programa de Pós-Graduação em Proteção de Plantas, Instituto Federal Goiano (IFG) - Campus Urutaí (GO), Brazil.

2Department of Biological Sciences Teachers, IFG - Campus Urutaí (GO), Brazil.

DOI: http://dx.doi.org/10.7322/abcshs.v41i3.910

\begin{abstract}
The objective of the present study was to identify and evaluate the content of information about dengue available on Brazilian websites. Thirty-two websites were selected for the analysis. For the evaluation of the content of information about dengue, a form was prepared with 16 topics grouped in six information blocks: etiology/ transmission, vector, control and prevention, disease/diagnosis, treatment and epidemiology. The websites were also evaluated according to the following criteria: authorship, update, language, interactivity, scientific basis and graphic elements. The results showed a predominantly lack of information in relation to the topics analyzed in each information block. Regarding the technical quality of the websites, only $28.1 \%$ showed some indication of scientific basis and $34.3 \%$ contained the date of publication or of the last update. Such results attested the low reliability of the selected websites. Knowing that the internet is an efficient mechanism for disseminating information on health topics, we concluded that the creation of such mechanisms to disseminate correct and comprehensive information about dengue is necessary in order to apply this useful tool in the prevention and control of the disease in Brazil.
\end{abstract}

Keywords: Aedes aegypti; dengue virus; database; access to information.

\section{RESUMO}

O presente estudo teve como objetivos identificar e avaliar o conteúdo das informações sobre dengue disponibilizadas em websites brasileiros. Foram selecionados 32 websites com caráter informativo para a análise. Para a avaliação do conteúdo das informações sobre dengue, utilizou-se um formulário composto de 16 tópicos agrupados em seis blocos de informação: etiologia/transmissão, vetor, controle e prevenção, doença/diagnóstico, tratamento e epidemiologia. Os websites também foram avaliados quanto aos seguintes critérios: autoria, atualização, linguagem, interatividade, fundamento científico e elementos gráficos. Os resultados demonstraram grande percentual de ausência de informações em relação aos tópicos analisados em cada bloco de informação. Quanto à qualidade técnica dos websites, verificou-se que apenas $28,1 \%$ apresentaram indicação de fundamentação científica e 34,3\% continham a data da publicação ou a última atualização das informações. Tais resultados atestaram a baixa confiabilidade dos websites. Sabendo que a internet é um eficiente mecanismo de difusão de informações sobre a saúde, conclui-se que é necessária a criação de mecanismos de disseminação de informações corretas e abrangentes sobre a dengue, aproveitando-se dessa ferramenta útil para a prevenção e o controle da doença no Brasil.

Palavras-chave: Aedes aegypti; vírus da dengue; base de dados; acesso à informação. 


\section{INTRODUCTION}

In the beginning, internet was interlinked to research laboratories and its use was restricted to the academic and military areas. But, from 1994 on, it has expanded commercially in Brazil ${ }^{1}$. Between 2000 and 2015, internet penetration has increased almost seven-fold, from 6.5 to $43 \%$ of the global population. The proportion of households with internet access advanced from $18 \%$ in 2005 to $46 \%$ in $2015^{2}$. Thus, the use of the World Wide Web is expressive. People search information that varies according to their specific needs ${ }^{3}$. According to Tomaél et al. ${ }^{4}$, this increase is related to varied internet characteristics, such as interactivity, sharing, speed, agility, digital data, multimedia functions, among others.

In this context, the search for health information has been reaching unprecedented levels ${ }^{5}$. Diseases, weight loss, health insurance and specific disease treatments are among the most searched health topics on the internet ${ }^{6}$. The fast and easy access to information on the internet can bring benefits to the population, promoting a better understanding of their condition, so that they can take conscious decisions to improve their health ${ }^{7}$. Besides, the information access through the internet contributes to awareness regarding the importance of treatments, improvement of the quality of life, prevention methods and early diagnosis of certain diseases, helping the governmental health system to disseminate important information ${ }^{8}$.

Considering that there are no mechanisms of website certification, of control or inspection of the information transmitted via internet, there is concern about its quality and veracity. Regarding health-related themes, incorrect contents on certain illnesses can not only favor their proliferation or aggravate the condition ${ }^{3}$, but also influence the performance of certain procedures that would help internet users in situations associated with disease prophylaxis.

It can also be said that the possibility of a fast and easy access to health and disease questions via internet can replace the search for health professionals, and, as a consequence, internet users may assume responsibility for their own healthcare ${ }^{9}$. Thus, the level of influence of the information found on internet has increased, which shows the importance of such information to be adequated. It is undeniable that the internet has opened a vast field of information source types. However, the high and evident probability of finding incorrect information raises a big question.

In this sense, several authors have already analyzed the quality and reliability of information about specific diseases and other themes available on the internet, such as Souza et al. ${ }^{10}$, Malafaia ${ }^{11}$, Malafaia \& Rodrigues ${ }^{12}$, Corrêa et al. ${ }^{13}$, Hirata et al. ${ }^{14}$ and Westin \& Zem-Mascarenhas ${ }^{15}$, who investigated the quality and adequacy of information available on Brazilian websites, respectively, on visceral leishmaniasis, Chagas disease, malaria, oral functions (breathing, sucking, swallowing, chewing, and speaking), coronary disease, and donation and transplants of organs. In general, these authors found almost no information on the contents analyzed, having also identified incorrect information and withholding of data (e.g., authorship, sources and references), which confer low reliability to the information. Additionally, these studies pointed to the fact that many of the websites do not explain technical terms, formatting makes access difficult, forums are not mediated by professionals, material is copied without the original citation or references, information is given with no scientific proof, and procedures are indicated without mentioning the importance of a medical opinion.

In this context, investigation on the quality of information about themes related to health available on the internet must be carried on. For this research, dengue was chosen as target disease, considering the scarcity of studies evaluating the content of information about it on websites ${ }^{16,17}$. Dengue is the most common arbovirus infection globally, with almost four billion people at risk $^{18,19}$. The number of dengue cases reported to World Health Organization (WHO) has increased steadily from an average of less than a thousand cases per year globally, in the 1950s, to more than three million cases in $2013^{20-22}$. These reports, however, greatly understate the problem and estimates the true number of annual apparent infections range from 50 to 200 million, with apparent infections being defined as all symptomatic infections, including those undetected by reporting systems. The most commonly cited range, including by WHO, is of 50 to 100 million apparent cases per year ${ }^{23}$. Although estimates of dengue deaths are less often reported, the most commonly cited number is around 20,000 deaths per year ${ }^{24}$.

If, on one hand, the lack of information or the presence of incorrect information can result in harm to population health, on the other hand, dissemination of correct and comprehensive information about dengue can be useful for its prevention and control in Brazil. Thus, our objective was to evaluate the content of information about dengue disseminated on Brazilian websites, as well as the technical quality of these websites.

\section{METHODS}

Initially, a survey was carried out involving Brazilian websites that present information about dengue. The search machine used was Google Brazil, and the period chosen was July $24^{\text {th }}$ to August $24^{\text {th }}, 2014$. The name of the disease and the name of its main transmitter - respectively, dengue and Aedes aegypti in inverted commas - were used as descriptors. The search was constrained to Brazil by using the option "pages from Brazil".

We established that the first 100 results should be evaluated, because, in general, these are the most accessed by users ${ }^{25}$. From the first 100 results, a selection of websites with information about the disease was made for further analysis, considering that the explicit objective of these sites was to publish information about some theme, in this case, dengue, or sites that, among other aims, also presented information about dengue. Websites that were not informative, or presented technical problems when trying access for two days, links to scientific articles, and repeated websites were excluded. After applying these criteria, 32 websites were analyzed. The website addresses are presented in Chart 1. 
For the analysis of the content of information about dengue, a form was prepared with 16 topics grouped in six information blocks: block 1) etiology/transmission; block 2) vector; block 3) control and prevention; block 4) disease/diagnosis; block 5) treatment; block 6) epidemiology (Chart 2). A key with correct information was prepared to help evaluate the content of websites.

Chart 1: Electronic addresses of the websites selected for this study

\author{
Addresses \\ 1. www.dengue.org.br \\ 2. www.minhavida.com.br/saude/temas/dengue \\ 3. pt.wikipedia.org/wiki/Dengue \\ 4. drauziovarella.com.br/letras/d/dengue \\ 5. www.combateadengue.com.br/o-que-e-dengue \\ 6. www.sobiologia.com.br/conteudos/Agua/Agua11.php \\ 7. www.suapesquisa.com/cienciastecnologia/dengue.htm \\ 8. www.cives.ufrj.br/informacao/dengue/den-iv.html \\ 9. www.abcdasaude.com.br/infectologia/dengue \\ 10. www.sms.fortaleza.ce.gov.br \\ 11. www.saude.goiania.go.gov.br/html/prevencao/dengue.shtml \\ 12. www.prefeitura.sp.gov.br/cidade/secretarias/saude/vigilancia_ \\ em_saude/dengue/index.php? $\mathrm{p}=3885$ \\ 13. http://saude.ig.com.br/ \\ 14. www.pjf.mg.gov.br/dengue/ \\ 15. www.mst.org.br/conteudo/28/dengue/ \\ 16. dengue.saude.es.gov.br/
}

17. www.abc.med.br/p/sinais.-symptoms-e-doencas/33243/dengue +saiba+mais+sobre+a+doenca+e+como+la+htmal

18. dengue.cecom.unicamp.br/?page_id=213

19. www.infoescola.com/doencas/dengue/

20. www.medicinapratica.com.br/tag/aedes-aegypti/

21. www.dedetizacao-consulte.com.br/dengue.asp

22. www.unioeste.br/projetos/unisol/projeto/c_biologia/dengue.htm

23. www.boasaude.com.br/artigos-de-saude/5327/-1/dengue.htm |

24. www.recife.pe.gov.br/especiais/dengue/index.php

25. www.brasilescola.com/doencas/dengue.htm

26. cefaleias.com.br/DENGUE-E-DOR-DE-CABECA

27. wikitravel.org/pt/Dengue

28. www.saudevidaonline.com.br/artigo45.htm

29. www.saudemedicina.com/sintomas-da-dengue

30. www4.faac.unesp.br/pesquisa/nos/olho_vivo/dengue.htm

31. symptomsdadengue.net.br

32. http://www.criasaude.com.br/doencas/dengue.html
It was based on information published on Manuais Normativos do Ministério da Saúde (Normative Manual of the Ministry of Health) and in scientific literature. The level of information (content) in each topic was ranked as "lacking", "correct" or "incorrect/incomplete", according to the key. The technical quality of the websites was also checked, according to the following criteria ${ }^{11}$ : authorship, update, language, interactivity, scientific basis and graphic elements (Chart 3 ). The websites considered "adequate" were those that were "correct" in all topics of the information blocks. Two evaluators (specialized in the field of biological sciences) assessed each website.

The data obtained for each information block were analyzed, resulting in a classification frequency for content and technical criteria. To access the dissimilarity relationship between different websites, it was employed a clustering analysis based on Euclidean distance. For this, the data were analyzed as a whole, attributing value 1 for complete information, value 2 for lack of information, and value 12 for partial/incomplete information. A frequency matrix was prepared and used to estimate the degree of dissimilarity between the websites using Euclidean distance calculated. To aid the relationship analysis between different websites, a dendrogram was constructed using the Unweighted Pair Group Method with Arithmetic Mean (UPGMA) clustering method. The quality adjustment of the dendrogram graphic projection was tested according to Mantel method normalized for 9,999 permutations. The analyses were made using the software Numerical Taxonomy System (NTSYSpc) version 2.2 ${ }^{26}$. The global distance mean was used as a cut-line and to define clusters.

\section{RESULTS AND DISCUSSION}

After the selection and ranking of the 32 website contents, we observed that all websites failed in giving complete information about some topic of the information blocks. Therefore, no website was considered "adequate", applying the parameters established in this study. This result can be related to the specificity of the key used here to evaluate the information.

The calculated Euclidean distances show that the websites share an expressive group of information, as indicated by the mean value of 0.44 and the range from 0.20 to 0.61 . The cluster analysis helped organize the websites in four main clusters, each one with specific characteristics (Figure 1). The resulting dendrogram yielded a high and significant adjustment to the originally calculated distance matrix, with a cophenetic correlation of 0.71 ( $\mathrm{p}<0.001$ for 9,999 permutations). Cluster A includes websites $(n=6)$ that, in average, received a positive response to the majority (64.6\%) of technical criteria (Figure 1). It was considered the most technically qualified, constituting the second major website cluster that presented complete information about dengue. In average, $12.5 \%$ of the information about dengue identified in each website were classified as complete. 
Chart 2: Form listing specific contents about dengue, used in the evaluation of Brazilian websites

\begin{tabular}{|c|c|c|c|}
\hline \multirow{2}{*}{ Specific criteria } & \multicolumn{2}{|c|}{ Yes } & \multirow{2}{*}{ No } \\
\hline & Complete & Incomplete & \\
\hline \multicolumn{4}{|l|}{ Block 1: etiology and transmission } \\
\hline T1. Does the website bring information about the etiologic agent for dengue and its characteristics? & $(\quad)$ & $(\quad)$ & ( \\
\hline T2. Does the website bring information about the way the disease is transmitted? & $(\quad)$ & $(\quad)$ & $(\quad)$ \\
\hline T3. Does the website bring information (sketch/illustration. about the disease transmission cycle? & $(\quad)$ & $(\quad)$ & $(\quad)$ \\
\hline $\begin{array}{l}\text { T4. Does the website explain the relationship between susceptibility and immunity to the } \\
\text { etiological agent? }\end{array}$ & $(\quad)$ & $(\quad)$ & ( \\
\hline \multicolumn{4}{|l|}{ Block 2: vector } \\
\hline V1. Does the website bring information about the biology of the vector? & $(\quad)$ & $(\quad)$ & $(\quad)$ \\
\hline V2. Does the website show clear photos or illustrations of the insect vector? & $(\quad)$ & $(\quad)$ & $(\quad)$ \\
\hline $\begin{array}{l}\text { V3. Does the website explain that the offspring of contaminated vectors are born with the } \\
\text { etiological agent for the disease? }\end{array}$ & $(\quad)$ & $(\quad)$ & $(\quad)$ \\
\hline \multicolumn{4}{|l|}{ Block 3: control and prevention } \\
\hline C1. Does the website bring information about dengue control/prophylaxis? & $(\quad)$ & $(\quad)$ & ( \\
\hline \multicolumn{4}{|l|}{ Block 4: disease and diagnosis } \\
\hline D1. Does the website inform that dengue is an acute febrile illness? & $(\quad)$ & $(\quad)$ & ( \\
\hline D2. Does the website bring information about the classifications of dengue cases? & $(\quad)$ & $(\quad)$ & $(\quad)$ \\
\hline D3. Does the website bring information about the clinic signs for each form of dengue manifestation? & $(\quad)$ & $(\quad)$ & $(\quad)$ \\
\hline D4. Does the website bring information about the ways to diagnose the disease? & $(\quad)$ & $(\quad)$ & $(\quad)$ \\
\hline \multicolumn{4}{|l|}{ Block 5: treatment and vaccine } \\
\hline T1. Does the website bring information about dengue treatment? & $(\quad)$ & $(\quad)$ & $(\quad)$ \\
\hline T2. Does the website bring information about the perspectives of creating a vaccine against dengue? & $(\quad)$ & $(\quad)$ & $(\quad)$ \\
\hline \multicolumn{4}{|l|}{ Block 6: epidemiology } \\
\hline E1. Does the website bring updated information about dengue epidemiology in Brazil? & $(\quad)$ & $(\quad)$ & ( \\
\hline E2. Does the website bring updated information about dengue epidemiology in other countries? & $(\quad)$ & $(\quad)$ & ( \\
\hline
\end{tabular}

Chart 3: Evaluation form related to the technical aspects of Brazilian websites

\section{Technical criteria}

1. Is(are) the author(s) and/or responsible person(s) for the content of the website explicit?

2. Does the website inform data on education and training of the author(s) and/or the responsible for the published content?

3. Does the website present the date when the information was published or reviewed?

4. Does the text contain mistakes in Portuguese?

5. Are there fields in the website so that the readers can write their opinion or questions on the content?

6. Is there any scientific basis to support the information made available on the website, e.g., a list of references in the end of the text?

\begin{tabular}{|c|c|c|}
\hline \multicolumn{3}{|c|}{ Evaluation } \\
\hline \multicolumn{2}{|c|}{ Yes } & No \\
\hline \multicolumn{2}{|c|}{$(\quad)$} & $(\quad)$ \\
\hline $\begin{array}{c}\text { Completely } \\
(\quad)\end{array}$ & $\begin{array}{c}\text { Superficially } \\
(\quad)\end{array}$ & $(\quad)$ \\
\hline \multicolumn{2}{|c|}{$(\quad)$} & $(\quad)$ \\
\hline \multicolumn{2}{|c|}{$(\quad)$} & $(1)$ \\
\hline \multicolumn{2}{|c|}{$(\quad)$} & $(\quad)$ \\
\hline $\begin{array}{l}\text { Updated } \\
\qquad(\quad)\end{array}$ & $\begin{array}{l}\text { Outdated } \\
(1)\end{array}$ & $(\quad)$ \\
\hline \multicolumn{2}{|c|}{$(\quad)$} & $(\quad)$ \\
\hline \multicolumn{2}{|c|}{()} & $(\quad)$ \\
\hline
\end{tabular}

7. Are there graphic elements (figures, images, sketches, graphs, tables, charts, etc.) that help understand the information published on the website?

8. Is the content exposed in such a way that the user can easily understand it? Are there difficult words or excess of technical terms? 
Cluster B includes websites $(n=3)$ that present the highest percentage of information considered complete (including all the information of Chart 2) and that received a positive response to technical criteria. In average, each website of this cluster presented $22.9 \%$ of information about dengue considered complete. This cluster also includes websites that presented the lowest percentage (also 22.9\%) of lack of information about dengue.

Cluster $\mathrm{C}(\mathrm{n}=7)$ includes half of the websites that did not receive a positive response to technical criteria (Figure 1), but present correct information. On the other hand, cluster D represents the websites $(n=16)$ that yielded the lowest percentage of information about dengue considered complete, being ranked as the least qualified cluster in terms of specific contents on the disease. In average, only $4.3 \%$ of the information about dengue in each website were considered complete. This cluster also includes websites with the highest percentage of information considered incomplete and lacking (in average, 95.7\%). Besides, this cluster includes the websites that received more negative responses to questions related to technical criteria (Figure 1), thus being considered the least qualified cluster. In each website, in average $61.7 \%$ of the technical criteria were not identified.

Regarding information of block 1 (question T1), no websites present complete information on the etiologic agent for dengue and its characteristics. The majority of websites (93.7\%) has incomplete or wrong information about the topic (Figure 2A), e.g., about the taxon corresponding to the virus that causes dengue. Incorrect information, indicating that the family to which the virus belongs is Flavivirus, was observed. This term refers to the genus of the etiological agent - the correct family is Flaviviridae. Errors like these may remain unnoticed, giving the false idea to the lay public that the information is correct. However, to those with knowledge in the area, it may indicate that the website is unreliable.

Incomplete information about the way the disease is transmitted (T2) was found in $87.5 \%$ of the websites (Figure 2A). It is worth mentioning that the proper knowledge of the way of dengue transmission can positively influence the procedures to be taken to prevent the process. Still regarding block 1, $40.6 \%$ and $46.8 \%$ of the websites do not present information on topics T3 (disease transmission cycle) and T4 (information on susceptibility and immunity to the etiological agent), respectively (Figure 2A).

Information block 2 was evaluated considering that dengue control is based only on eliminating the mosquito vector (Aedes aegypti). Respectively, $81.2 \%$ and $15.6 \%$ of the websites present incomplete or no information on the biology of the mosquito vector (V1) (Figure 2B). It was also checked whether the websites present clear photos or illustrations of the A. aegypti; only $37.5 \%$ has good pictures (V2); $25 \%$ has images in which the mosquito could not be correctly identified; and $37.5 \%$ does not use any visual aid.

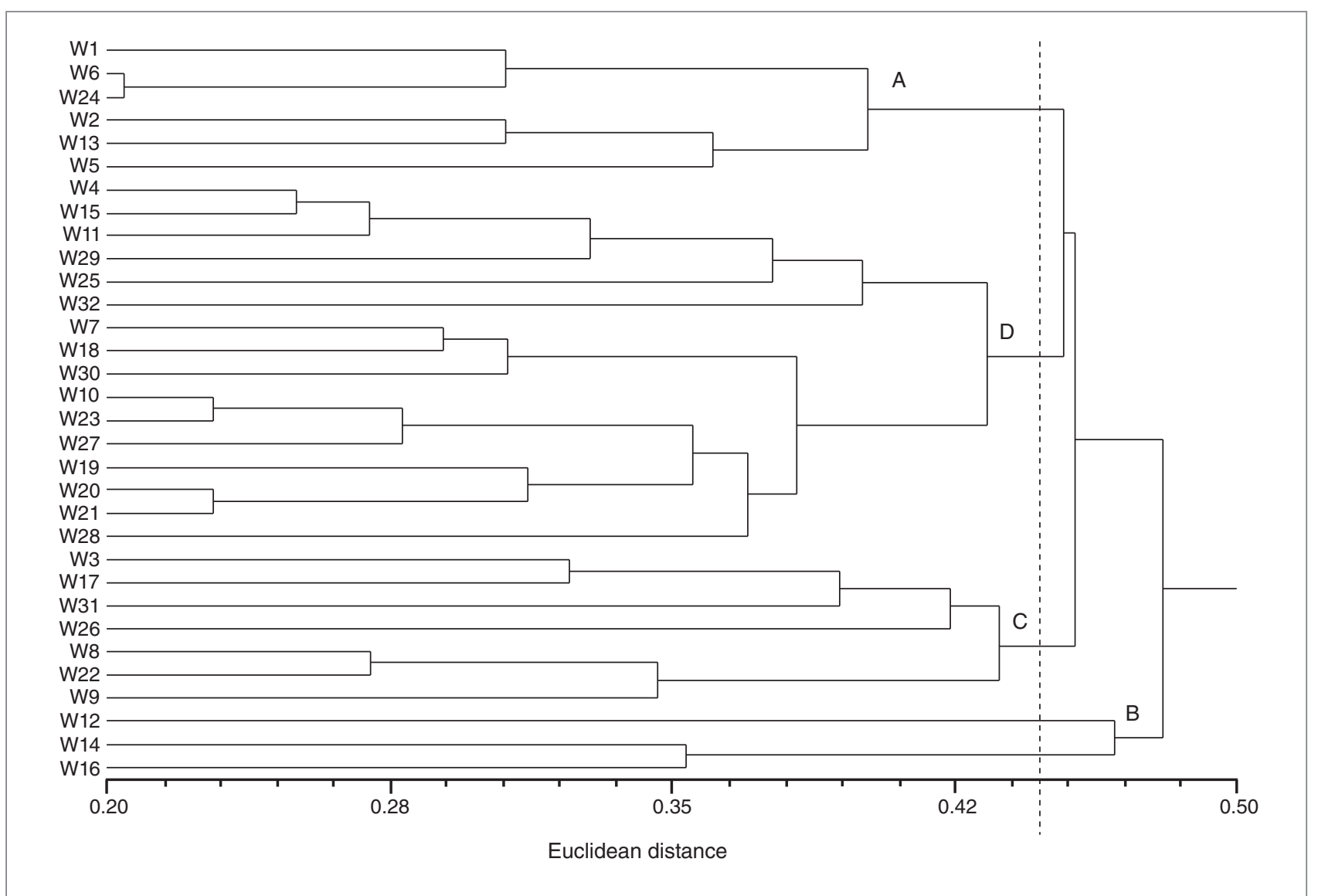

Figure 1: Dendrogram of similarity between the evaluated websites, considering all evaluation criteria (of specific content on dengue and those related to technical criteria). The letters $W$ refer to the websites shown in Table 1 
Most of the websites (90.6\%) do not explain that the offspring of infected (female) mosquito vectors could acquire the virus by transovarian transmission (V3), as discussed by Singhi et al. ${ }^{27}$. This shows that the majority of the websites is outdated regarding the mosquito vector. If this information is presented in a complete and correct form, it can significantly contribute to the fight against the virus, consequently influencing dengue control and/or prevention.

The analysis of information from block 3 , in which our aim was to evaluate the websites in terms of information about dengue control/ prophylaxis, showed that $93.7 \%$ of the websites present incomplete information (C1) (Figure 2C). As mentioned before, the fight against A. aegypti is still the main form of dengue control and prevention. This can be achieved via environmental changes, such as better water supply, antimosquito protection for water tanks or underground reservoirs, or chemical control by fogging. Information about these procedures was found on the websites. However, the biological control (e.g., larvae-eating fish), which is an alternative for fighting against the dengue vector, is not mentioned. Pereira and Oliveira ${ }^{28}$ demonstrated the potential of such control by using fish of the species Poecilia reticulata as biologic control of $A$. aegypti larvae in a domestic environment. However, it is important to consider that this strategy, although interesting, does not apply to most insect vector breeding.

As discussed by Santos et al. ${ }^{29}$, a better knowledge of dengue and of the symptoms aggravation can influence the survival of a person infected with the virus. Even if a specific treatment still does not exist, a group of measures is used towards the patient's recovery. Therefore, the objective of block 4 was to evaluate whether the websites present information on the disease/diagnosis. The majority of the websites (56.2\%) does not inform that dengue is an acute febrile disease (D1) (Figure 2C).

In relation to topic $\mathrm{D} 2$, which refers to the classification of dengue cases, only $9.3 \%$ of the websites do not present them and $90.6 \%$ shows incomplete information (Figure 2C). The high percentage of websites with incomplete information results from the fact that none of them is updated with the new dengue classification reviewed by WHO and adopted since 2014. In this new edition, dengue cases are classified as dengue without warning signs, dengue with warning signs and severe dengue. This new classification proved to be more sensitive in detecting severe cases, improving the care of patients and decreasing mortality ${ }^{30,31}$.

Topics D3 and D4 of block 4 yielded information on clinical signals for each form of the disease manifestation and on the forms of diagnosis, respectively. Knowledge on these subjects positively contributes to the disease's fast diagnosis and treatment ${ }^{32}$. A high percentage of incomplete information resulted for topic D3 (93.7\%). In relation to topic D4, 56.2\% of the websites present incomplete information, and $43.7 \%$ does not bring any information on the forms of diagnosis (Figure 2C).

As there is no specific treatment for dengue, medications for symptoms characteristics of acute febrile disease are commonly used instead ${ }^{33}$. Thus, analgesics and antipyretics are indicated to control fever and headache, whereas medications containing acetylsalicylic acid and non-steroidal anti-inflammatories are avoided, because these compounds stimulate hemorrhagic manifestations. The use of oral rehydration serum is also recommended ${ }^{34}$.
Regarding the development of a specific vaccination against dengue, Wan et al. ${ }^{35}$ state that, although there is vaccine testing, this issue is still a challenge for the scientific community. Aspects such as the immunization capacity against the four serotypes, assurance on possible emergence of new serotypes, disease aggravation after vaccination, and vaccination strategies constitute problems in this line of research ${ }^{27}$.

In this context, the objective of block 5 was to evaluate the information about dengue treatments (T1) and the perspectives of creating a vaccine against it (T2). The results for topic T1 showed that only $15.6 \%$ of the websites present complete information about dengue treatments and $75 \%$ presents incomplete information. On the other hand, only $6.2 \%$ of the websites have information about the perspectives of creating a vaccine against dengue (T2), and the majority (78.1\%) does not even comment it (Figure 2D).

Regarding the analysis of information of block 6 , which evaluated whether the websites brought recent information about dengue epidemiology, we observed that only $21.8 \%$ contains correct information on the theme (E1) (Figure 2D) and 68.7\% presents no information at all (E1). The majority of the websites (84.3\%) does not present data on the disease in other countries (E2), and $15.6 \%$ presents outdated information (Figure 2D). The lack of epidemiologic data may hinder the identification of areas of higher prevalence and incidence of the disease worldwide.

As discussed by Barreto \& Teixeira ${ }^{36}$, the search for information about dengue epidemiology and the analyses carried out by researchers and governmental health organizations aim at identifying the determining factors that improve prevention and control strategies. Thus, the dissemination of correct information about dengue epidemiological data in the media, including websites, enhances the construction of knowledge, which will consequently influence decision making ${ }^{37}$.

This study also analyzed the technical quality of the websites, following the criteria presented in Chart 3. Even with more than half of the websites (65.6\%) citing the authorship and/or responsibility for the content (Q1: is(are) the author(s) and/or responsible person(s) for the content of the website explicit?), only $21.8 \%$ presents information on the authors' professional performances (Q2: does the website inform data on education and training of the author(s) and/or the responsible for the published content?), which diminishes the reliability of the information and may prevent the reader from following the exposed procedures. Besides, the low percentage of websites (34.3\%) that shows the date of publication or review of the information $(\mathrm{Q} 3$ : does the website present the date when the information was published or reviewed?) corroborates the low reliability of the text. It was also observed that only $21.8 \%$ of the websites present errors in Portuguese (Q4: does the text contain mistakes in Portuguese?), and only 37.5\% provides fields for the readers to express their opinions or make questions on the content $(\mathrm{Q} 5$ : are there fields on the website so that the readers can write their opinion or questions on the content?).

Another aspect that did not favor the reliability of the websites was the lack of scientific basis (Q6: is there any scientific basis to support the information made available on the website, e.g., a list of references in the end of the text?). A small percentage of them cites 


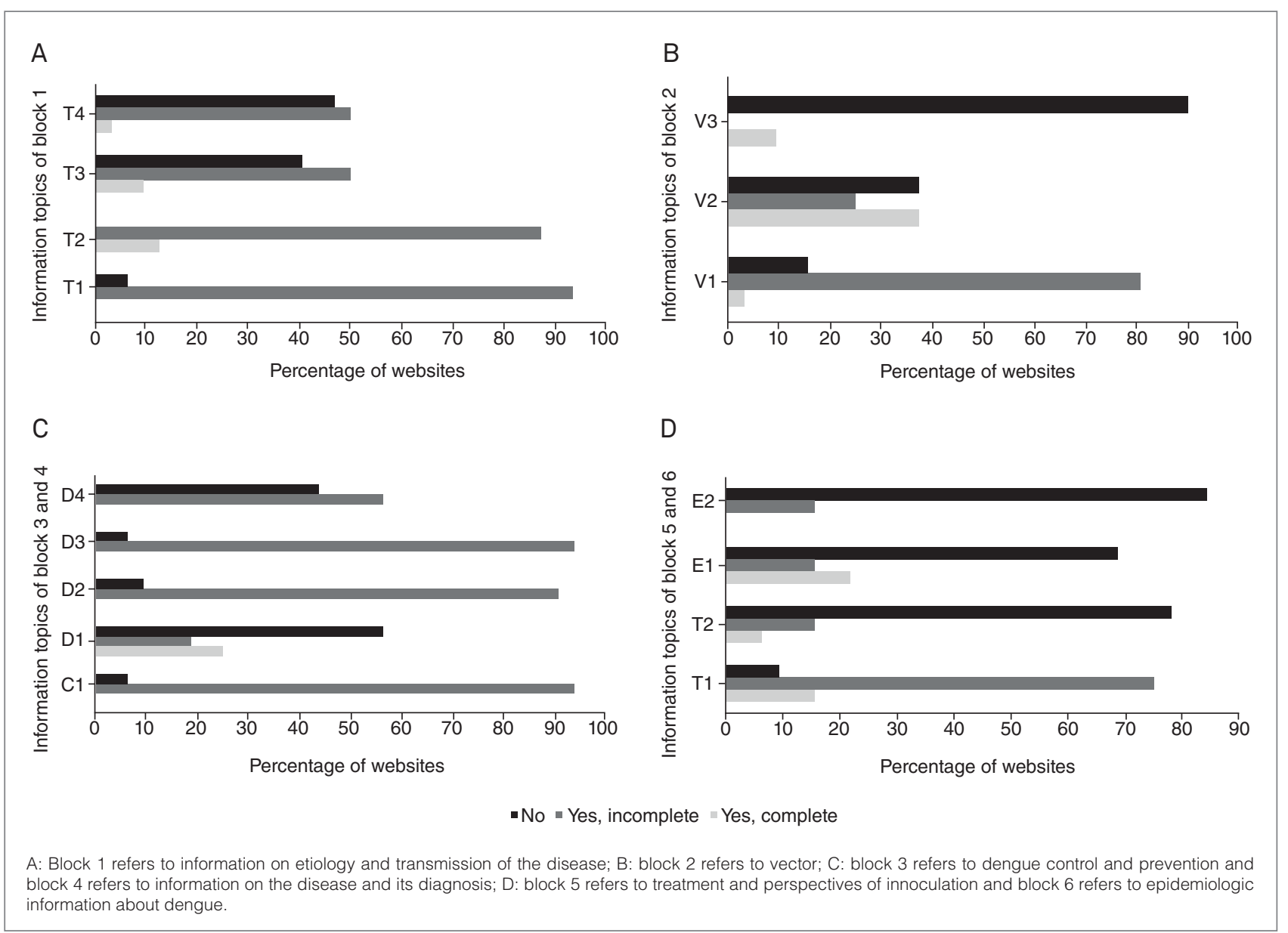

Figure 2: Evaluation of the accuracy of information about dengue available in the 32 Brazilian websites. The information topics were defined in Chart 2

scientific references (28.1\%), even if they are outdated. As discussed by Malafaia ${ }^{11}$, the fact that websites do not present scientific basis prevents the internet user from pursuing the subjects discussed in the text. Thus, the impression is that the information comes from the authors' empirical knowledge, and not from scientifically attested experience ${ }^{38}$.

On the other hand, $75 \%$ of the websites contain graphic elements (figures, images, sketches, graphs, tables, charts, etc.) that aided the understanding of the information (Q7: are there graphic elements (figures, images, sketches, graphs, tables, charts, etc.) that help understand the information published on the website?). In the majority of them (96.8\%), the content evolves so as to make understanding easier, with no difficult words or excess of technical terms (Q8: is the content exposed in such a way that the user can easily understand it; are there difficult words or excess of technical terms?). This constitutes a positive aspect.

\section{CONCLUSION}

Based on the results exposed, we can say that the present study revealed a serious failure of websites in making information about dengue, an important disease nowadays, available. There is inaccurate information on relevant topics about dengue. Most of the websites present incomplete or wrong information on the theme. Another negative point observed in the websites, in general, was the lack of technical criteria that could add reliability to them.

In this sense, there is the concern on the access to misleading and incomplete information by internet users, which could lead them to inadequate procedures and actions, causing financial and health problems. It is suggested that public organizations responsible for health or medical societies take the initiative to create mechanisms to disseminate reliable and quality information about dengue on the web, so that the large potential of internet as an information source can be exploited, promoting, in a positive way, dengue prevention and control.

\section{ACKNOWLEDGEMENTS}

The authors thank the Instituto Federal Goiano, Campus Urutaí, by granting financial assistance to this study (Process No. 23219.000132/2015-76). 


\section{REFERENCES}

1. Sorj B. Brasil@povo.com: a luta contra a desigualdade na Sociedade da Informação. Rio de Janeiro: Jorge Zahar; Brasília/DF: Unesco; 2003.

2. Information and Communication Technologies (ICT). Statistics confirm ICT revolution of the past 15 years [cited 2016 Jan 21]. Available from: https://www.itu.int/net/pressoffice/press_releases/2015/17.aspx

3. McCully SN, Don BP, Updegraff JA. Using the internet to help with diet, weight, and physical activity: results from the Health Information National Trends Survey (HINTS). J Med Internet Res. 2013;15(8):e148. http://dx.doi.org/10.2196/jmir.2612

4. Tomaél MI, Catarino ME, Valentim MLP, Almeida Junior OF, Silva TE. Avaliação de fontes de informação na internet: critérios de qualidade. Inf Soc: Est. 2001;11(2):1-14.

5. Moretti FA, Oliveira VE, Silva EMK. Acesso a informações de saúde na internet: uma questão de saúde pública? Rev Assoc Med Bras. 2012;58(6):650-8.

http://dx.doi.org/10.1590/S0104-42302012000600008

6. Fox S, Duggan M. Health online 2013: $35 \%$ of U.S. adults have gone online to figure out a medical condition; of these, half followed up with a visit to a medical professional [cited 2014 Oct 13]. Available from: http://www.pewinternet.org/files/old-media/ Files/Reports/PIP_HealthOnline.pdf

7. Silva EV, Castro LLC. A internet como forma interativa de busca de informação sobre saúde pelo paciente [cited 2014 Oct 13]. Textos de La CiberSociedad [Internet], 2008. Available from: http://www. cibersociedad.net/public/articles/textos_0bkua.doc

8. Bastos BG, Ferrari DV. Internet e educação ao paciente. Arq Int Otorrinolaringol. 2011;15(4):515-22.

http://dx.doi.org/10.1590/S1809-48722011000400017

9. Santana S, Pereira AS. Da utilização da internet para questões de saúde e doença em Portugal: possíveis repercussões na relação médico-doente? Acta Med Port. 2007;20(1):47-57.

10. Souza CLN, Luz ZP, Rabello A. Análise da informação sobre a leishmaniose visceral disponível em portais brasileiros da rede mundial de computadores - Internet. Rev Soc Bras Med Trop. 2008:41(4):352-7. http://dx.doi.org/10.1590/S0037-86822008000400006

11. Malafaia G. Análise de informações sobre a doença de Chagas disponíveis em websites brasileiros na rede mundial de computadores (internet). Arq Bras Ciên Saúde. 2009;34(3):188-95. http://dx.doi.org/10.7322/abcs.v34i3.123

12. Malafaia G, Rodrigues AS. Análise de informações sobre a malária disponíveis em websites brasileiros na rede mundial de computadores (internet). Brasília Med. 2010;47(2):177-87.

13. Corrêa CC, Ferrari DV, Berretin-Felix G. Qualidade, abrangência e legibilidade de websites relacionados às funções orofaciais. Int Arch Otorhinolaryngol. 2013;17(4):358-62. http://dx.doi.org/10.1055/s-0033-1351372

14. Hirata DM, Queiroz NR, Souza RC, Oliveira LB, Martins WA. Qualidade da informação na internet sobre coronariopatia. Rev Bras Cardiol. 2010;23(1):39-46.

15. Westin UM, Zem-Mascarenhas SH. Infodemiologia: análise das informações sobre doação e transplante de órgãos. Ciênc Cuid Saúde. 2014;13(2):381-7. http://dx.doi.org/10.4025/cienccuidsaude.v13i2.18967

16. Gomes AJM, Silva LCB, Assis TSM, Carvalho FD. Avaliação da qualidade da informação disponível sobre a dengue em portais brasileiros da rede mundial de computadores. Educ Tecnol. 2013;18(3):59-70.
17. Pereira Neto AF, Paolucci R. Qualidade da informação em sites de dengue: análise de uma experiência inovadora. Rio de Janeiro: ENSP/Fiocruz; 2014.

18. Brady OJ, Gething PW, Bhatt S, Messina JP, Brownstein JS, Hoen AG, et al. Refining the global spatial limits of dengue virus transmission by evidence-based consensus. PLoS Negl Trop Dis. 2012;6(8):e1760. http://dx.doi.org/10.1371/journal.pntd.0001760

19. Stanaway JD, Shepard DS, Undurraga EA, Halasa YA, Coffeng LE, Brady OJ, et al. The global burden of dengue: an analysis from the Global Burden of Disease Study 2013. Lancet Infect Dis. 2016;S1473-3099(16)00026-8.

http://dx.doi.org/10.1016/S1473-3099(16)00026-8

20. World Health Organization (WHO). DengueNet [cited 2015 Apr 24]. Available from: http://www.who.int/csr/disease/dengue/ DengueNetFlyer2006.pdf

21. World Health Organization (WHO). Vector borne and neglected tropical diseases. [cited 2015 Jan 24] Available from: http://www. searo.who.int/entity/vector_borne_tropical_diseases/en/

22. Pan American Health Organization (PAHO). Number of reported cases of dengue and severe dengue (SD) in the Americas, by country. 2014. [cited 2016 Jan 20] Available from: http://www. paho.org/hq/index.php?option=com_topics\&view=readall\&cid=3 273\&ltemid $=40734 \&$ lang $=e n$

23. Bhatt S, Gething PW, Brady OJ, Messina JP, Farlow AW, Moyes $\mathrm{CL}$, et al. The global distribution and burden of dengue. Nature. 2013;496(7446):504-7.

http://dx.doi.org/10.1038/nature12060

24. World Health Organization (WHO). Dengue and severe dengue. [cited 2015 Apr 24] Available from: http://www.who.int/ mediacentre/factsheets/fs117/en/

25. Watertown M. Search engine marketing firm iProspect survey confirms importance of visibility on the first three pages of search results. [cited $2014 \mathrm{Apr} 13$ ] Available from: http://www.prweb.com/ releases/2004/04/prweb120172.htm

26. Rohlf FJ. NTSYS-pc: Numerical Taxonomy and Multivariate Analysis System, version 2.2e. New York: Exeter Software; 1997.

27. Singhi S, Kissoon N, Bansal A. Dengue e dengue hemorrágico: aspectos do manejo na unidade de terapia intensiva. J Pediatr. 2007;83(2 Supl):S22-35.

http://dx.doi.org/10.1590/S0021-75572007000300004

28. Pereira BB, Oliveira EA. Determinação do potencial larvófago de Poecilia reticulata em condições domésticas de controle biológico. Cad Saúde Coletiva. 2014;22(3):241-5. http://dx.doi.org/10.1590/1414-462X201400030004

29. Santos SL, Cabral ACSP, Augusto LGS. Conhecimento, atitude e prática sobre dengue, seu vetor e ações de controle em uma comunidade urbana do Nordeste. Ciênc Saúde Coletiva. 2011;16(Supl 1):1319-30.

http://dx.doi.org/10.1590/S1413-81232011000700066

30. Governo do Estado do Ceará. Monitoramento dos casos de dengue Semana Epidemiológica (SE) 01 a 23/2016.[cited 2016 Jun 10]. Available from: http://www.saude.ce.gov.br/index.php/ boletins?download $=825 \% 3$ Aboletim-da-dengue

31. Lima FR, Croda MG, Muniz DA, Gomes IT, Soares KR, Cardoso MR, et al. Evaluation of the traditional and revised World Health Organization classifications of dengue cases in Brazil. Clinics. 2013;68(10):1299-304. http://dx.doi.org/10.6061/clinics/2013(10)02 
32. Xavier ALR, Freitas MS, Loureiro FM, Borghi DP, Kanaan S Manifestações clínicas na dengue: diagnóstico laboratorial. J Bras Med. 2014;102(2):7-14.

33. World Health Organization (WHO). Dengue and dengue haemorrhagic fever [cited 2014 Oct 20]. Available from: http:// www.who.int/mediacentre/factsheets/fs117/en/\#/

34. Brasil. Ministério da Saúde. Diretrizes Nacionais para a Prevenção e Controle de Epidemias de Dengue. Brasília: Ministério da Saúde; 2009.

35. Wan SW, Lin CF, Wang S, Chen YH, Yeh TM, Liu HS, et al. Current progress in dengue vaccines. J Biomed Sci. 2013;20:37. http://dx.doi.org/10.1186/1423-0127-20-37
36. Barreto ML, Teixeira MG. Dengue no Brasil: situação epidemiológica e contribuições para uma agenda de pesquisa. Estud Av. 2008;22(64):53-72.

http://dx.doi.org/10.1590/S0103-40142008000300005

37. Villela EFM, Almeida MA. Mediações da informação em saúde pública: um estudo sobre a dengue. Rev Electron Comun Inf Inov Saúde. 2012;6(1):39-49. http://dx.doi.org/10.3395/reciis.v6i1.606

38. Silva LVER, Mello Jr JF, Mion O. Avaliação das informações sobre rinite alérgica em sites brasileiros na rede mundial de computadores (internet). Rev Bras Otorrinolaringol. 2005;71(5):590-7. http://dx.doi.org/10.1590/S0034-72992005000500008 